\title{
The effect of the $\beta$-2-adrenergic agonist clenbuterol or implantation with oestradiol plus trenbolone acetate on protein metabolism in wether lambs
}

\author{
BY O. BOHOROV*, P. J. BUTTERY†, J. H. R. D. CORREIA \\ AND J. B. SOAR \\ Department of Applied Biochemistry and Food Science, University of Nottingham School \\ of Agriculture, Sutton Bonington, Nr Loughborough, Leics. LE12 5RD
}

(Received 24 January 1986 - Accepted 19August 1986)

1. The effects of Revalor (trenbolone acetate plus oestradiol) implantation or the inclusion of clenbuterol (a $\beta$-2-adrenergic agonist) in the diet of wether lambs was studied. Using continuous intravenous infusion of $\left[{ }^{3} \mathrm{H}\right]$ tyrosine the fractional synthetic rate of mixed protein from three separate muscles was measured.

2. Clenbuterol slightly increased growth rate but had a significant $(P<0.02)$ effect on food conversion efficiency. The weight and protein content of the longissimus dorsi and vastus lateralis muscles were increased but no such changes were observed for the vastus intermedius. For the longissimus dorsi at least the increase was probably achieved by a reduction in fractional degradation rate of the muscle protein.

3. Revalor significantly increased the growth rate and food conversion efficiency of the animals. This increase was not specific for muscle. Estimated degradation rates of muscle protein were lower in the treated animals.

4. The possible mode of action of these materials was discussed. The results obtained again highlight the importance of protein degradation in controlling growth.

There is widespread interest in improving the efficiency of lean deposition in farm animals. Two potential ways of inducing this is to promote growth in general, e.g. by using anabolic agents, or by reducing fat deposition, e.g. by means of $\beta$-agonists. During the last few years it has been established that some $\beta$-adrenergic agonists possess well-defined repartitioning properties which are realized at very-low feed inclusion rates. These agents (e.g. clenbuterol, cimaterol and salbutamol) improve animal performance and carcass characteristics, increasing both protein deposition and lean tissue, decreasing fat deposition and improving food conversion efficiency. It is suggested that some $\beta$-2-adrenergic agonists as feed additives will have a dramatic effect on the livestock industry (Dalrymple, 1984; Dalrymple et al. 1984). The exact mode of action of $\beta$-agonists is still unknown. With laboratory animals (mainly rats) it has been reported that compounds with $\beta$-adrenergic properties activate $\beta$-receptors in adipocytes and through the increased synthesis of cyclic adenosine-3',5'monophosphate (cAMP) they activate lipolysis in adipose tissue (Fain \& Garcia-Sainz, 1983) and thermogenesis (Rothwell \& Stock, 1983; Rothwell et al. 1984). Some findings published recently however indicate that clenbuterol and isoproternenol were five to ten times more potent as anti-lipogenic than as lipolytic agents (Duquette \& Muir, 1985). Few studies have been reported on their effects on protein metabolism and no studies concerning the mechanism of action in farm animals have apparently been reported.

Implantation with anabolic compounds is another approach for improving animal performance. It was shown in a number of experiments that combined implants containing compounds with androgenic and oestrogenic activity are more effective in stimulating growth in castrate males than either of these compounds when administered alone. Implantation with trenbolone acetate (TBA) and $17 \beta$-oestradiol as a combined implant

* Present address: Department of Physiology, Research Institute of Animal Breeding, 2232 Kostinbrod, Bulgaria.

$\uparrow$ For reprints. 
(Revalor) increased live-weight gain and nitrogen retention in growing castrate male lambs (Coelho et al. 1981; Quirke \& Sheeham, 1981; Kellas et al. 1982; Sinnett-Smith et al. 1983; Singh et al. 1984). At present the mode of action of these anabolic agents on protein metabolism is not clear.

The purpose of the present experiment was to study the effects of a selective $\beta$-2-adrenergic agonist clenbuterol and an anabolic implant Revalor on fractional rates of muscle protein synthesis (FSR) and calculated muscle degradation rates in wether lambs.

\section{EXPERIMENT AL}

\section{Animals and diet}

An experiment was carried out with twenty-eight wether lambs (Suffolk $\times$ Clun Forest) randomly divided into four groups. Lambs from the first group (four lambs) were slaughtered at the beginning of the trial. Longissimus dorsi, vastus lateralis and vastus intermedius muscles were dissected and weighed. Samples from them were stored at $-15^{\circ}$ and assayed for crude protein $(\mathrm{N} \times 6 \cdot 25)$. The other twenty-four lambs were divided into three groups: control group, group implanted with Revalor (Roussel-Uclaf, Paris) and the group receiving $10 \mathrm{mg} / \mathrm{kg}$ clenbuterol in the diet. Revalor $(52.5 \mathrm{mg}$ TBA and $7.5 \mathrm{mg}$ $17 \beta$-oestradiol) was implanted subcutaneously at the base of the ear. In order to achieve adequate distribution of clenbuterol it was mixed with a small quantity of starch and this was then mixed with the main bulk of the treatment diet. During the 5 weeks of the experiment, lambs from the three groups were fed ad lib. on a pelleted diet containing (g/kg): barley (225), oats (450), grassmeal (200), mineral mix (25) and Nutramol (Rumenco, Burton-on-Trent) 100. One group received the same diet with clenbuterol added. The diet provided $(\mathrm{g} / \mathrm{kg}): 871$ dry matter, 138 crude protein and $11.8 \mathrm{MJ}$ metabolizable energy $/ \mathrm{kg}$ dry matter. Feed intake and animal weights were recorded weekly. During the experiment one lamb from the clenbuterol group was removed due to ill-health.

\section{Experimental procedure}

After $37 \mathrm{~d}$ of treatment, protein synthetic rates were assessed using the continuous-infusion technique described by Garlick et al. (1973). In three consecutive days six lambs (two lambs randomly selected from each group per day) were put in metabolism crates with free access to food and water. One day before the infusion, catheters were inserted into both jugular veins. Animals were infused with $\mathrm{L}$-[side chain $\left.2,3-{ }^{3} \mathrm{H}\right]$ tyrosine (Amersham International plc, Amersham, Bucks) diluted to $13 \mu \mathrm{Ci} / \mathrm{ml}$ in $130 \mu \mathrm{M}$-L-tyrosine $(58 \mu \mathrm{Ci} / \mu \mathrm{mol})$. The rate of infusion, approximately $8 \mathrm{ml} / \mathrm{h}$ was measured for each animal individually. During the infusion blood samples were withdrawn at 45 min intervals. After centrifugation plasma was removed and stored at $-40^{\circ}$ until determination of plasma free tyrosine specific radioactivity. At the end of the infusion, lambs were deeply anaesthetized with Sagatal (sodium pentobarbitone; May and Baker Ltd, Dagenham). The infusion was stopped and samples from longissimus dorsi, vastus lateralis and vastus intermedius muscles were rapidly excised (less than 2 min after the end of the infusion) and frozen in liquid $\mathrm{N}_{2}$ and stored at $-40^{\circ}$. The same three muscles from the other side of the carcass were dissected, weighed and stored at $-15^{\circ}$. The specific radioactivity of protein-bound and free tyrosine in muscles was determined in samples prepared according to Sinnett-Smith et al. (1983) by the method of Garlick \& Marshall (1972) and Garlick et al. (1973). L-Tyrosine decarboxylase (EC 4.1.1.25; Sigma Chemical Co., Poole, Dorset) was used for enzymic conversion of tyrosine into tyramine. The concentration of the latter was measured fluorimetrically by the nitroso-naphthol method of Waalkes \& Undenfriend (1957) and radioactivity was determined using liquid-scintillation counting. 
Table 1. Effect of a dietary $\beta$-agonist, clenbuterol, or implantation with Revalor (17 $\beta$-oestradiol plus trenbolone acetate), on weight gain and food conversion efficiency in wether lambs

(Animals were weighed $33 \mathrm{~d}$ after beginning of the experiment; no. of lambs in parentheses)

\begin{tabular}{|c|c|c|c|c|c|c|c|}
\hline & \multirow[b]{2}{*}{$\begin{array}{l}\text { Control } \\
\text { (8) }\end{array}$} & \multirow[b]{2}{*}{$\begin{array}{l}\text { Clenbuterol } \\
(7)\end{array}$} & \multirow[b]{2}{*}{$\begin{array}{l}\text { Revalor } \\
\text { (8) }\end{array}$} & \multirow[b]{2}{*}{$\begin{array}{l}\text { Pooled } \\
\text { SED }\end{array}$} & \multicolumn{3}{|c|}{$\begin{array}{l}\text { Statistical significance of } \\
\text { difference between groups }\end{array}$} \\
\hline & & & & & $\begin{array}{l}\text { Control } v . \\
\text { clenbuterol }\end{array}$ & $\begin{array}{l}\text { Control } v \text {. } \\
\text { Revalor }\end{array}$ & $\begin{array}{c}\text { Clenbuterol } v . \\
\text { Revalor }\end{array}$ \\
\hline Initial wt (kg) & $27 \cdot 56$ & $27 \cdot 67$ & $27 \cdot 87$ & $1 \cdot 39$ & NS & NS & NS \\
\hline Wt gain $(\mathrm{kg})$ & $12 \cdot 19$ & $13 \cdot 00$ & $14 \cdot 81$ & $1 \cdot 19$ & NS & $P<0.05$ & NS \\
\hline ADLWG (kg) & 0.369 & $0 \cdot 394$ & $0 \cdot 449$ & 0.0361 & NS & $P<0.05$ & NS \\
\hline $\begin{array}{l}\text { Daily dry matter } \\
\text { intake }(\mathrm{kg})\end{array}$ & $1 \cdot 7$ & $1 \cdot 5$ & 1.7 & 0.15 & NS & NS & NS \\
\hline FCE & 4.93 & $4 \cdot 11$ & 4.08 & $0 \cdot 29$ & $P<0.02$ & $P<0.01$ & NS \\
\hline
\end{tabular}

ADLWG, average daily live-weight gain; FCE, food conversion efficiency ( $\mathrm{kg}$ food intake/ $\mathrm{kg}$ weight gain); NS, not significant $(P>0 \cdot 1)$, SED, SE of difference.

Protein-bound and free tyrosine content in muscles (for calculation of $\mathbf{R}$ value, see Garlick et al. 1973) was determined by high-performance liquid chromatography using a gradient eluting mixture of acetate buffer, methanol and tetrahydrofuran (Jones \& Gilligan, 1983).

Plasma free tyrosine specific radioactivity for each lamb was measured in the last three blood samples, i.e. when the plateau value was reached. To ensure this blood samples from three control animals were withdrawn at 45-min intervals and used for determination of free tyrosine specific radioactivity throughout the infusion. The entire build-up curve illustrated that the plateau value is reached well before $6 \mathrm{~h}$. Tyrosine flux, whole-body protein synthesis and FSR in muscles were calculated using the equations given by Garlick et al. (1973) and Waterlow et al. (1978).

Facilities were not available for carrying out carcass analysis on radioactive samples. At the end of the experiment the last two lambs from each group were killed and the kidney fat was removed and weighed. After $24 \mathrm{~h}$ at $2^{\circ}$ the carcasses were divided into two portions by a transverse cut at the 12 th rib. Longissimus dorsi area and fat depth were measured. Protein content in muscles was estimated after Kjeldahl digestion and an automatic phenol-hypochlorite reaction (Davidson et al. 1970). Protein deposition was calculated as the difference between protein content in muscles of lambs killed at the beginning and those killed at the end of the trial.

\section{Statistical analysis}

The statistical significance of differences between groups was calculated by analysis of variance. Differences between the groups were assumed to be not significantly different at $P>0 \cdot 10$.

\section{RESULTS}

The addition of $10 \mathrm{mg}$ clenbuterol $/ \mathrm{kg}$ to the diet markedly increased food conversion efficiency $(P<0.02)$ and also, as indicated in Table 1, there was a tendency for an increase in daily live-weight gain. Examination of the weights of individual muscles confirmed the myogenic nature of this material, at least for the longissimus dorsi $(P<0.05)$, and, to a smaller extent, for the vastus lateralis muscle $(P<0 \cdot 1)$, but no indication of an increase 


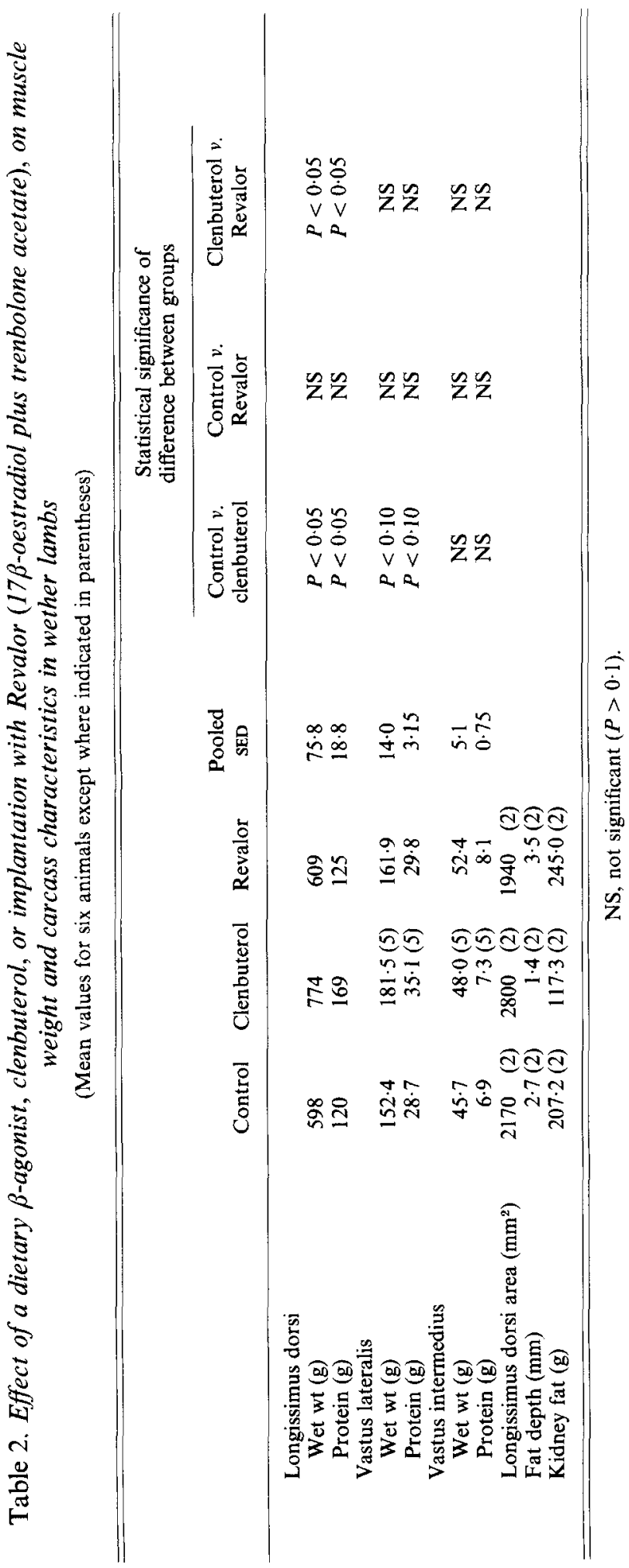


Table 3. Fractional muscle protein synthesis (FSR) and plasma tyrosine flux in muscles of wether lambs given a dietary $\beta$-agonist, clenbuterol, or implanted with Revalor (17 $\beta$-oestradiol plus trenbolone acetate)

(No. of lambs shown in parentheses)

\begin{tabular}{|c|c|c|c|c|c|c|c|}
\hline & \multirow[b]{2}{*}{$\begin{array}{l}\text { Control } \\
\text { (6) }\end{array}$} & \multirow[b]{2}{*}{$\begin{array}{c}\text { Clenbuterol } \\
\text { (5) }\end{array}$} & \multirow[b]{2}{*}{$\begin{array}{l}\text { Revalor } \\
\text { (6) }\end{array}$} & \multirow[b]{2}{*}{$\begin{array}{l}\text { Pooled } \\
\text { SED }\end{array}$} & \multicolumn{3}{|c|}{$\begin{array}{l}\text { Statistical significance of } \\
\text { difference between groups }\end{array}$} \\
\hline & & & & & $\begin{array}{l}\text { Control } v . \\
\text { clenbuterol }\end{array}$ & $\begin{array}{l}\text { Control } v \text {. } \\
\text { Revalor }\end{array}$ & $\begin{array}{c}\text { Clenbuterol } v . \\
\text { Revalor }\end{array}$ \\
\hline Tyrosine flux (mmol/h) & 4.88 & $4 \cdot 50$ & $4 \cdot 89$ & $0 \cdot 51$ & NS & NS & NS \\
\hline \multicolumn{8}{|l|}{$\begin{array}{l}\text { FSR (from homogenate } \\
\text { free-tyrosine SRA) } \\
(\% / d)\end{array}$} \\
\hline Longissimus dorsi & $6 \cdot 28$ & $5 \cdot 97$ & $5 \cdot 15$ & $1 \cdot 58$ & NS & NS & NS \\
\hline Vastus lateralis & $5 \cdot 38$ & 7.04 & 3.62 & 1.25 & NS & NS & $P<0.02$ \\
\hline Vastus intermedius & $7 \cdot 96$ & $7 \cdot 66$ & $7 \cdot 46$ & $1 \cdot 77$ & NS & NS & NS \\
\hline \multicolumn{8}{|l|}{$\begin{array}{l}\text { Minimum FSR (from } \\
\text { plasma free tyrosine } \\
\text { SRA) }(\% / d)\end{array}$} \\
\hline Longissimus dorsi & $2 \cdot 46$ & $2 \cdot 86$ & $3 \cdot 10$ & $0 \cdot 72$ & NS & NS & NS \\
\hline Vastus lateralis & 3.95 & $4 \cdot 43$ & $2 \cdot 31$ & $1 \cdot 05$ & NS & NS & $P<0.10$ \\
\hline Vastus intermedius & $4 \cdot 89$ & $4 \cdot 92$ & $5 \cdot 28$ & 0.94 & NS & NS & NS \\
\hline
\end{tabular}

SRA, specific radioactivity; NS, not significant $(P>0 \cdot 1)$; SED, SE of difference.

Table 4. Characteristics of the initial slaughter group of four lambs $(\mathrm{g})$

\begin{tabular}{|c|c|c|}
\hline & Mean & SE \\
\hline Body-wt $(\mathrm{kg})$ & $25 \cdot 7$ & $0 \cdot 14$ \\
\hline \multicolumn{3}{|l|}{ Longissimus dorsi } \\
\hline Wet wt & 337.0 & $35 \cdot 4$ \\
\hline Protein & 57.7 & 6.01 \\
\hline \multicolumn{3}{|l|}{ Vastus lateralis } \\
\hline Wet wt & $90 \cdot 3$ & $4 \cdot 80$ \\
\hline Protein & $17 \cdot 11$ & 1.52 \\
\hline \multicolumn{3}{|l|}{ Vastus intermedius } \\
\hline Wet wt & $30 \cdot 5$ & 1.40 \\
\hline Protein & $4 \cdot 72$ & $0 \cdot 24$ \\
\hline
\end{tabular}

in the weight of the vastus intermedius was noted (Table 2). The total protein content of the muscles showed similar trends (Table 2). As indicated above it was not possible to carry out full-scale carcass dissection on the animals used for FSR measurements but analysis of two uninfused animals in each treatment group clearly showed a marked reduction in the fat content of the clenbuterol-treated animals (Table 2). Visual inspection of the infused animals confirmed this.

The difficulty of knowing whether the plasma pool or the intracellular pool (approximately equivalent to homogenate pool in the present study) is the true precursor of amino acids for protein synthesis makes precise interpretation of the FSR values difficult (see Waterlow et al. 1978). There was no indication of any significant change in the FSR of the longissimus dorsi on clenbuterol treatment. Thus it appears, for the longissimus dorsi at 
Table 5. Fractional gain* of muscle protein $(\% / d)$ of wether lambs given a dietary $\beta$-agonist, clenbuterol, or implanted with Revalor (17 $\beta$-oestradiol plus trenbolone acetate)

(No. of lambs shown in parentheses)

\begin{tabular}{|c|c|c|c|c|c|c|c|}
\hline & \multicolumn{3}{|c|}{ Fractional gain } & \multirow[b]{2}{*}{$\begin{array}{l}\text { Pooled } \\
\text { SED }\end{array}$} & \multicolumn{3}{|c|}{$\begin{array}{l}\text { Statistical significance of } \\
\text { difference between groups }\end{array}$} \\
\hline & $\begin{array}{c}\text { Control } \\
(6)\end{array}$ & $\begin{array}{c}\text { Clenbuterol } \\
\text { (5) }\end{array}$ & $\begin{array}{l}\text { Revalor } \\
\text { (6) }\end{array}$ & & $\begin{array}{l}\text { Control } v \text {. } \\
\text { clenbuterol }\end{array}$ & $\begin{array}{l}\text { Control } v . \\
\text { Revalor }\end{array}$ & $\begin{array}{c}\text { Clenbuterol } v \text {. } \\
\text { Revalor }\end{array}$ \\
\hline Longissimus dorsi & $1 \cdot 88$ & $2 \cdot 50$ & 1.97 & $0 \cdot 279$ & $P<0.05$ & NS & $P<0.10$ \\
\hline Vastus lateralis & $1 \cdot 36$ & $1 \cdot 80$ & 1.45 & 0.260 & NS & NS & NS \\
\hline Vastus intermedius & 1.00 & 1.09 & $1 \cdot 35$ & $0 \cdot 248$ & NS & NS & NS \\
\hline
\end{tabular}

NS, not significant $(P>0 \cdot 1)$; SED, SE of difference.

* Calculated from the following relation:

(final protein content of muscle-initial protein content of muscle) $\times 100$ mean protein content of muscle.

least, that the marked increase in the deposition rate must have come from a decrease in the degradation rate of the muscle protein.

The flux of tyrosine through the plasma pool is presented in Table 3. No significant differences were noted. It was not possible to correct the flux for tyrosine intake or oxidation rate.

Revalor treatment significantly increased body-weight gain (Table 1) without increasing food intake. There were no significant changes in the weight of individual muscles although there was a tendency for the:- to be an increase in all muscles of a magnitude similar to that of the total body-weight gain (Tables 1 and 2). There were indications of an increase in body fat in direct contrast to clenbuterol treatment.

Body-weight and muscle wet weights and protein contents of the initial slaughter group of four lambs are given in Table 4.

\section{DISCUSSION}

The selective $\beta$-2-adrenergic agonist clenbuterol had similar effects on the lambs to those seen in the more extensive production trials reported by Baker et al. (1984) using a similar dose of the compound but with a longer experimental period ( 8 weeks). The responses to Revalor were also similar to those reported following several other trials with sheep (see Buttery \& Sinnett-Smith, 1984).

The extensive repartitioning seen on treatment with $\beta$-agonists has been reported for several ruminant and non-ruminant species, e.g. chickens (Dalrymple et al. 1983; Muir et al. 1985), pigs (Jones et al. 1985), lambs (Baker et al. 1984; Dalrymple et al. 1985; Beermann et al. 1985b) and steers (Ricks et al. 1984). The effects on the carcass lipid content are dramatic and are readily discernible even by a casual visual inspection of the carcass. $\beta$-Agonists have marked effects on lipid metabolism. The effects were originally thought to be on lipolysis although recent observations have suggested that an inhibition of lipogenesis may be more important (see p. 99) and that there is a reduction in total fat-cell numbers (Coleman et al. 1985).

Treatment with clenbuterol had a marked effect on the weight and protein content of the longissimus dorsi and a smaller effect on vastus lateralis but there was no increase in both weight and protein content of the vastus intermedius. There was no indication that 
the FSR of the longissimus dorsi was stimulated which is not in agreement with the studies of Emery et al. (1984) using the gastrocnemius muscle from rats treated with either clenbuterol or fenoterol. Protein degradation rates are very difficult to determine in large farm animals. While it is possible to obtain a mean rate of protein gain during the experiment the FSR measurement only applies to the last day of the experiment. Especially with treatments lasting several weeks and employing hormone and hormone-like materials it is not possible to estimate reliably the mean FSR. Likewise the true protein gain on the last day of the experiment cannot be estimated reliably unless numerous animals are killed. In the present work no significant change was observed in the FSR of the longissimus dorsi on clenbuterol treatment, nevertheless there was a marked increase in protein deposition rate (Table 5) and it must be concluded that the degradation rate was depressed. This decrease in degradation rate confirms the earlier work by Li \& Jefferson (1977) and Tischler (1981), albeit with a non-selective $\beta$-agonist and in different species. The vastus lateralis muscle did not show such a marked increase in the rate of gain of protein. There was, however, no indication of a depression in degradation rate but the synthetic rate was numerically higher than that of the control animals. These trends were seen irrespective of the precursor pool used in the protein synthesis calculations. Examination of the ratio of the specific activities of the homogenate free pool: plasma free amino acid pool showed no effect of treatment $(P>0 \cdot 1)$. The vastus intermedius showed no response to clenbuterol treatment.

Differences in the response of different muscles to hormonal treatment has been noted previously (e.g. Rannels \& Jefferson, 1980; Deshaies et al. 1981; Odedra \& Millward, 1982). These differences have been attributed to differences in the proportion of fast- and slow-twitch fibres in the muscle. In sheep there is not a marked difference in the fibre types seen in different muscles as is seen in other species (e.g. the rat, R. A. Lawrie, personal communication). Beermann et al. (1985a) have shown that treatment of lambs with cimaterol reduced the numbers of slow-contracting oxidative fibres in the deep medial semitendinosus and superficial lateral semitendinosus muscles but had no effect on the semimembranosus or longissimus dorsi muscles. The possibility exists that the difference in response seen between muscles in the present study could be correlated with the ratio of the fibre types in the muscles studied. This suggestion obviously requires further investigation. In the rat it has been shown that $\beta$-2-adrenergic receptor density varies between muscles of differing fibre type, the slow oxidative muscles, e.g. soleus, having more receptors than the mixed fibre type muscles, e.g. gastrocnemius (Williams et al. 1984). It is not apparent if the same situation applies to the sheep. We do not know if the responses in muscle seen on $\beta$-agonist treatment are due to a direct action of the compound or are a result of the changes seen in endogenous hormone patterns (see for example Emery et al. 1984; Ricks et al. 1984) or changes in other circulating metabolic messengers. However, Stiles et al. (1984) state that treatment with $\beta$-agonists does increase muscle cAMP content, an expected response to a direct action of $\beta$-agonists.

The treatment of the animals with the combined trenbolone-oestradiol implant (Revalor) had the expected influence on growth rate and food conversion efficiency (Buttery \& Sinnett-Smith, 1984). Unlike clenbuterol treatment in the present experiment, there was evidence of a general increase in both muscle and fat. The food intake of the control and the Revalor-treated animals was not different $(P>0 \cdot 1)$. Again the main influence of treatment would appear to be a reduction in fractional degradation rate, particularly in the longissimus dorsi and the vastus lateralis. This observation confirms the previous results from this laboratory with trenbolone alone in female animals (rats, Vernon \& Buttery, 1976, 1978; sheep, Sinnett-Smith et al. 1983) and circumstantial evidence from muscle cathepsin D activity of Revalor-treated wethers (Sinnett-Smith et al. 1983). Recently with 
cattle Lobley et al. (1985) noted a reduction in $N^{\tau}$-methyl histidine excretion of Revalortreated steers. The reason why the synthetic androgen trenbolone needs oestrogens present to exert its effect is difficult to explain. Although trenbolone acts on muscle protein synthesis in the opposite way to testosterone (Martinez et al. 1984), it does influence the numbers of androgen cytosolic receptors (Sinnett-Smith et al. 1987). Oestrogens are often said to act via growth hormone (Buttery \& Sinnett-Smith, 1984) although there are indications that this is not the case (for example, see Muir et al. 1983). Also if growth hormone were involved it would be expected that there would be an increase in FSR but this was not seen in the present study or with the oestrogenic substance Zeranol (Sinnett-Smith et al. 1983).

Unfortunately the lack of precision and expense of the continuous-infusion technique to measure protein FSR makes interpretation of experiments with large domestic species difficult. The findings presented here do, however, again indicate the importance of protein degradation rate in the control of muscle protein deposition in fast-growing animals manipulated with two quite different agents.

The authors gratefully acknowledge a fellowship for O. B. from the International Atomic Energy Agency, Vienna, and for J.H. R.D.C. from the North Atlantic Treaty Organisation. The authors wish to thank Miss C. Essex and Mr D. Bozon for their assistance during the experiment and Hoechst (UK) and Boehringer Ingleheim (W. Germany) for donations of Revalor and clenbuterol respectively.

\section{REFERENCES}

Baker, P. K., Dalrymple, R. H., Ingle, D. L. \& Ricks, C. A. Journal of Animal Science 59, 1256-1261.

Beermann, D. H., Fishell, V. K., Hogue, D. E., Ricks, C. A. \& Dalrymple, R. H. (1985a). Journal of Animal Science 61, Suppl. 1, 254, Abstr. 116.

Beermann, D. H., Hogue, D. E., Dalrymple, R. H. \& Ricks, C. A. (1985b). Journal of Animal Science 61, Suppl. 1, 255, Abstr. 117.

Berne, R. S., Noakowski, J. \& Bechtel, P. J. (1985). Journal of Animal Science 61, Suppl. 1, 256, Abstr. 119.

Buttery, P. J. \& Sinnett-Smith, P. A. (1984). In Manipulation of Growth in Farm Animals, pp. 21 l-232 [J. R. Roche and D. O'Callaghan, editors]. Boston: Montinus Nijhoff.

Coelho, J. F. S., Galbraith, H. \& Topps, J. H. (1981). Animal Production 32, 261-266.

Coleman, M. E., Everen, P. A. \& Smith, S. B. (1985). Journal of Animal Science 61, Suppl. 1, 264, Abstr. 140.

Dalrymple, R. H. (1984). In Pork Industry Conference, University of Illinois, pp. 93-104. Illinois: University of Illinois.

Dalrymple, R. H., Baker, P. K. \& Ricks, C. A. (1984). In Proceedings of 1984 Georgia Nutrition Conference for the Feed Industry, pp. 111-118. Georgia, USA: University of Georgia.

Dalrymple, R. H., Baker, P. K., Doscher, M. E., Ingle, D. L. \& Ricks, C. A. (1985). Journal of Animal Science 61, Suppl. 1, 256.

Dalrymple, R. H., Ricks, C. A., Baker, P. K., Pensack, J. M., Ginger, P. E. \& Ingle, D. L. (1983). Federation Proceedings 42, 668, Abstr.

Davidson, J., Mathison, J. \& Bone, A. M. (1970), Analyst 95, 181-193.

Deshaies, Y., Willemot, J. \& Leblanc, J. (1981). Canadian Journal of Physiology and Pharmacology 59, 113-121.

Duquette, P. F. \& Muir, L. A. (1985). Journal of Animal Science 61, Suppl. 1, 165, Abstr. 141.

Emery, P. W., Rothwell, N. J., Stock, M. J. \& Winter, P. D. (1984). Bioscience Reports 4, 83-91.

Fain, J. N. \& Garcia-Sainz, J. A. (1983). Journal of Lipid Research 24, 945-966.

Garfick, P. J. \& Marshall, I. (1972). Journal of Neurochemistry 19, 577-583.

Garlick, P. J., Millward, D. J. \& James, W. P. T. (1973). Biochemical Journal 136, 935-945.

Jones, B. N. \& Gilligan, J. P. (1983). Journal of Chromatography 266, 471-482.

Jones, R. W., Easter, R. A., McKeith, F. K. \& Bechtel, P. J. (1985). Journal of Animal Science 61, $905-913$.

Kellas, L. J., Suleiman, A. H., Galbraith, H., Topps, J. H. \& Chesworth, J. M. (1982). Animal Production 34, 396, Abstr.

Li, J. B. \& Jefferson, L. D. (1977). American Journal of Physiology 232, E243-E249.

Lobley, G. E., Connell, A., Mollison, G. S., Brewer, A., Harris, C. I. \& Bunchan, V. (1985). British Journal of Nutrition 54, 681-694.

Martinez, J. A., Buttery, P. J. \& Pearson, J. T. (1984). British Journal of Nutrition 52, 515-521. 
Muir, L. A., Wien, S., Duquette, P. F., Ricks, E. L. \& Cordes, E. H. (1983). Journal of Animal Science 56, 1315-1323.

Muir, L. A., Wien, S., Duquette, P. F. \& Olson, G. (1985). Journal of Animal Science 61, Suppl. 1, 263.

Odedra, B. R. \& Millward, D. J. (1982). Biochemical Journal 204, 663-672.

Quirke, J. E. \& Sheeham, W. (1981). Irish Journal of Agricultural Research 20, 125-135.

Rannels, S. R. \& Jefferson, L. S. (1980). American Journal of Physiology 238, E564-E572.

Ricks, C. A., Dalrymple, R. H., Baker, P. K. \& Ingle, D. L. (1984). Journal of Animal Science 59, 1247-1255.

Rothwell, N. J. \& Stock, M. J. (1983). Journal of Physiology 340, 62P.

Rothwell, N. J., Stock, M. J. \& Winter, P. D. O'B. (1984). Proceedings of the Nutrition Society 43, 71 A.

Singh, S. B., Galbraith, H., Henderson, G. D. \& Forbes, G. (1984). Proceedings of the Nutrition Society 43, 41 A.

Sinnett-Smith, P. A., Dumelow, N. W. \& Buttery, P. J. (1983). British Journal of Nutrition 50, 225-234.

Sinnett-Smith, P. A., Palmer, C. A. \& Buttery, P. J. (1987). Hormone and Metabolic Research (in the Press).

Stiles, G. L., Caron, M. G. \& Lefkowitz, R. J. (1984). Physiological Review 64, 661-743.

Tischler, M. E. (1981). Life Science 28, 2569-2576.

Vernon, B. G. \& Buttery, P. J. (1976). British Journal of Nutrition 36, 575-579.

Vernon, B. G. \& Buttery, P. J. (1978). Animal Production 26, 1-9.

Waalkes, T. P. \& Udenfriend, S. (1957). Journal of Laboratory and Clinical Medicine 50, 733-736.

Waterlow, J. C., Garlick, P. J. \& Millward, D. J. (1978). Protein Turnover in Mammalian Tissues and in the Whole Body. Amsterdam: North-Holland.

Williams, R. S., Caron, M. G. \& Daniel, K. (1984). American Journal of Physiology 246, E160-E167. 